\title{
ROMANIA VERSUS BULGARIA: A SHORT ANALYSIS OF THE COMPETITIVENESS OF SEASIDE TOURISM
}

\author{
Mihai Costea ${ }^{1}$, Cristian-Valentin Hapenciuc ${ }^{2}$, Gabriela Arionesei ${ }^{3}$
}

\begin{abstract}
This research compares tourism competitiveness of two neighboring countries, Romania and Bulgaria, which have many similarities economically as well as from a geopolitical and historical perspective. Despite these similarities, immediately after the 1990s, which marked the fall of the communist regime, the tourism phenomenon in the two countries had divergent evolutions. As the tourism industry in Bulgaria, especially its seaside tourism, underwent unprecedented development, the tourism activity in Romania systematically lost its competitiveness. The factors affecting the appearance and increase of such a difference are of interest to the Romanian seaside tourism. To generate the answer to this problem, we perform a series of comparative analyses with data from the World Economic Forum, in terms of the Travel and Tourism Competitiveness Report (20112015), 'the National Authority for Tourism of Romania, and the National Institute of Statistics from Romania and Bulgaria. We identified a series of constitutive elements relating to the success of the Bulgarian seaside tourism and a sequence of deficiencies in the strategic and organizational maneuvers of the tourism activity at the Romanian seaside.
\end{abstract}

JEL Classification Numbers: L83, P52 DOI: http://dx.doi.org/10.12955/cbup.v4.800

Keywords: Romania, Bulgaria, tourism competitiveness, Romanian seaside, Bulgarian seaside.

\section{Introduction}

The dynamism of the tourism industry and the freedom of markets in the industry favor the fresh capital infusions in new geographical zones with a strong tourism potential that lead to an unprecedented development of the tourism activity and their holiday destinations (Boșcoianu, Costea, \& Codreanu, 2015, p. 85). In other words, investment, cumulated with a series of strategies, legislation favorable to the development of tourism, and a marketing policy adapted to a rapidly changing market and in which tourists become more demanding every day, will finally lead to an organic increase in the number of players in the industry. This includes public and private organizations with a tourism profile in receiving countries and, inevitably, will result in internal and external competition.

In this context, the tourism industry of different countries had begun to make sustained efforts, both from a human resource point of view and from that of material, financial, and informational, to develop competitiveness in the tourism activity internationally. Though, at the general level, countries with advanced economies can easily impose a dominant position in the tourism market, because of the competitive advantages sustained by their general level of development and the volume of public and private investments in their tourism industry and connected fields. A series of developing countries have gradually emerged and are beginning to recover systematically from the differences registered at the level of performance in tourism and on different axes of competitiveness.

This work aims to establish whether Romania is a country with recovery in tourism. However, to advance this research, we analyze the phenomenon of competitiveness by comparing Romania with the neighboring country of Bulgaria. We chose Bulgaria because it possesses many similarities to Romania, economically and from a geopolitical and historical perspective. Both countries experienced the communist regime and both joined the European Union in the same year (i.e. 2007). The climate and the landscape are generally similar, and until the 1990s, the tourism practiced in the two countries was at a similar level of performance. If we focus strictly on the tourism potential of the two countries, we can effortlessly find many similarities in cultural and natural and historical heritage that enables several forms of tourism, e.g. mountain, cultural, ecological, adventure, seaside, rural, and business.

Despite these similarities, immediately after the 1990s, which marked the fall of the communist regime, the tourism phenomenon in the two countries diverged separately. As the tourism industry in

\footnotetext{
${ }^{1}$ Mihai Costea, Ștefan cel Mare University of Suceava, Suceava, Romania, mihai_costeaa@yahoo.com

${ }^{2}$ Cristian-Valentin Hapenciuc, Ștefan cel Mare University of Suceava, Suceava, Romania, valentinh@seap.usv.ro

${ }^{3}$ Gabriela Arionesei, Ștefan cel Mare University of Suceava, Suceava, Romania, gabriela.arionesei@gmail.com
} 
Bulgaria, especially from the seaside tourism perspective, underwent positive development, with a remarkable linearity, the tourism activity in Romania systematically lost its competitiveness, at least when compared with the main competitors at the regional level. The factors that determined the appearance and increase of these differences is the general crux of our research and for which we propose to find an answer.

In recent years, with the increase of international competition, Romania has initiated many approaches to revitalize the local tourism industry, through investing (still modest) in general infrastructure of transport and tourism, national and international promotional campaigns, and fiscal facilities for private economic establishments. We attempt to quantify the results of these efforts and, implicitly, the level of competitiveness of tourism activity in Romania, by comparing Romania with Bulgaria, its neighbor at the South of the Danube. We will base this on the Travel \& Tourism Competitiveness Index (TTCI), an indicator proposed by the World Economic Forum (WEF). Thus, after a concise presentation of the calculus methodology of the pillars around which this indicator articulates, we achieve a comparison of the two countries from results obtained for each pillar of competitiveness.

Because seaside tourism represents a basic form of tourism activity in both Romania and Bulgaria, we considered it appropriate to narrow the sphere of research and focus exclusively on this segment. We highlight a series of constitutive elements relating to the success of the Bulgarian seaside together with a sequence of deficiencies relating to strategic and organizational maneuvers of the tourism activities at the Romanian seaside.

\section{Literature Review}

The overall economic competitiveness, and, implicitly, that of tourism are fields of great interest in literature. The most well-known entity in this field and, possibly, the most representative, is the World Economic Forum, which every other year publishes a vast report of the tourism competitiveness (The Travel and Tourism Competitiveness Report, 2015) that mirrors the performances of about 140 national economies, numerically quantified by the Travel and Tourism Competitiveness Index.

Until now, the topic of tourism competitiveness was of maximum interest for many researchers. For example, Poon (1993), who was a pioneer in the study of competitiveness in the tourism field, indicated four key principles that any tourism destination should respect to become competitive with other destinations. These were: (1) put the environment on the map, (2) make tourism a top sector of the local economy, (3) strengthen the channels on the market, and not least of all (4) build a very dynamic private sector, "which generate competition" (the underlining of the authors). Ioncică, Petrescu, and Ioncică (2008) considered that, at both the micro- and macro-economic levels, the novelty aspect that influences competitiveness in the tourism sector is the intensity of competitiveness (competition). This is both internally and internationally determined by the phenomena of globalization of the economy and the rapidity of technological changes, especially in the field of computer science and telecommunications. Each will determine a major impact on the hospitality industry.

From a conceptual point of view, the term "competitiveness" can be defined in different forms. Nevertheless, the most accepted definition of tourism competitiveness stems from the general economic theory that refers to market mechanisms and components of tourism industry which can successfully maintain the attractiveness of a tourism destination (Hong, 2008, p. 43). In a study belonging to Dwyer, Forsyth, and Rao (2000, p. 9) on the competitiveness of prices in tourism, the term "competitiveness" is defined as a general concept referring to the difference of prices cumulated with modifying rates of currency exchange, levels of productivity in the tourism field, and qualitative factors that affect the attractiveness of a destination. In the same year, Hasan (2000, p. 239) stated that the term, "tourism competitiveness", refers to the ability of a destination to create tourism products with added value, while maintaining a position in the market higher than the competitor destinations.

Beginning with Poon (1993), many studies and research referred to the topic of tourism competitiveness in a relatively single-minded way. This was the case with the study of Ritchie \& Crouch (1993), which attempted to explain the dynamics of the phenomenon of competitiveness in international tourism. Later, Chon and Mayer (1995) brought reflection to the study of Crouch and Ritchie, by considering a basic characteristic of the services, i.e. intangibility. Murphy, Pritchard, and Smith (2000) indicated that to be competitive, a tourism destination must consider both the 
environment and the infrastructure, because these two elements have a strong influence on the perception of tourists regarding that destination. Enright and Newton (2005, pp. 339-350) considered a destination as competitive only if it could attract and meet the requirements of tourists with its competitiveness, as determined by a set of factors specific to the tourism activity with a larger set influencing the providers of tourism services. Other studies contributing to understanding the phenomenon of tourism competitiveness include Mazanec, Wöber, and Zins (2007), Gomezelj and Mihalič (2008), Crouch (2010), Zhang, Gu, Gu, and Zhang (2011), Ivanov and Webster (2013), and Navickas and Malakauskaite (2015).

Closely related to the field of tourism competitiveness is that of determining the destination's image. Many have researched this phenomenon, both before and after Poon's writings, and include studies of Hu and Ritchie (1993), Gallarza, Saura, and García (2002), Hsu, Wolfe, and Kang (2004), Bonn, Joseph, and Dai (2005), Chen and Tsai (2007), Chi and Qu (2008), Qu, Kim, and Im (2011), and Prayag and Ryan (2012).

\section{Methodology}

There are many studies and models for analyzing the differences between the tourism activity of different countries, but, by far, one of the most known is that of the Travel and Tourism Competitiveness Index (TTCI). From a methodological respect, the TTCI was used to evaluate a series of elements that were the basis of developing the tourism industry in different countries. This index (or indicator) has three categories of variables, around which the competitiveness of the tourism sector in a certain country emanates, and these variables take the form of the following sub-indices:

- the legislative system, with direct or indirect involvement in the tourism sector;

- the business environment and the infrastructure; and

- the natural, cultural, and human resources involved in tourism activities.

Each sub-index is formed on the basis of the main pillars that characterize aspects affecting the tourism industry. These include specific laws on the tourism sector, the environment and its sustainability, security and safety, health and hygiene, general infrastructure of transport (air, ground), specific infrastructure of tourism, the degree of competitiveness for prices, human and cultural resources, and information, technology, and communication (IT\&C) infrastructure (Figure 1). In addition, each pillar among those listed comprise a series of individual variables.

Figure 1: Components of the Travel \& Tourism Competitiveness Index (TTCI) in the year 2013

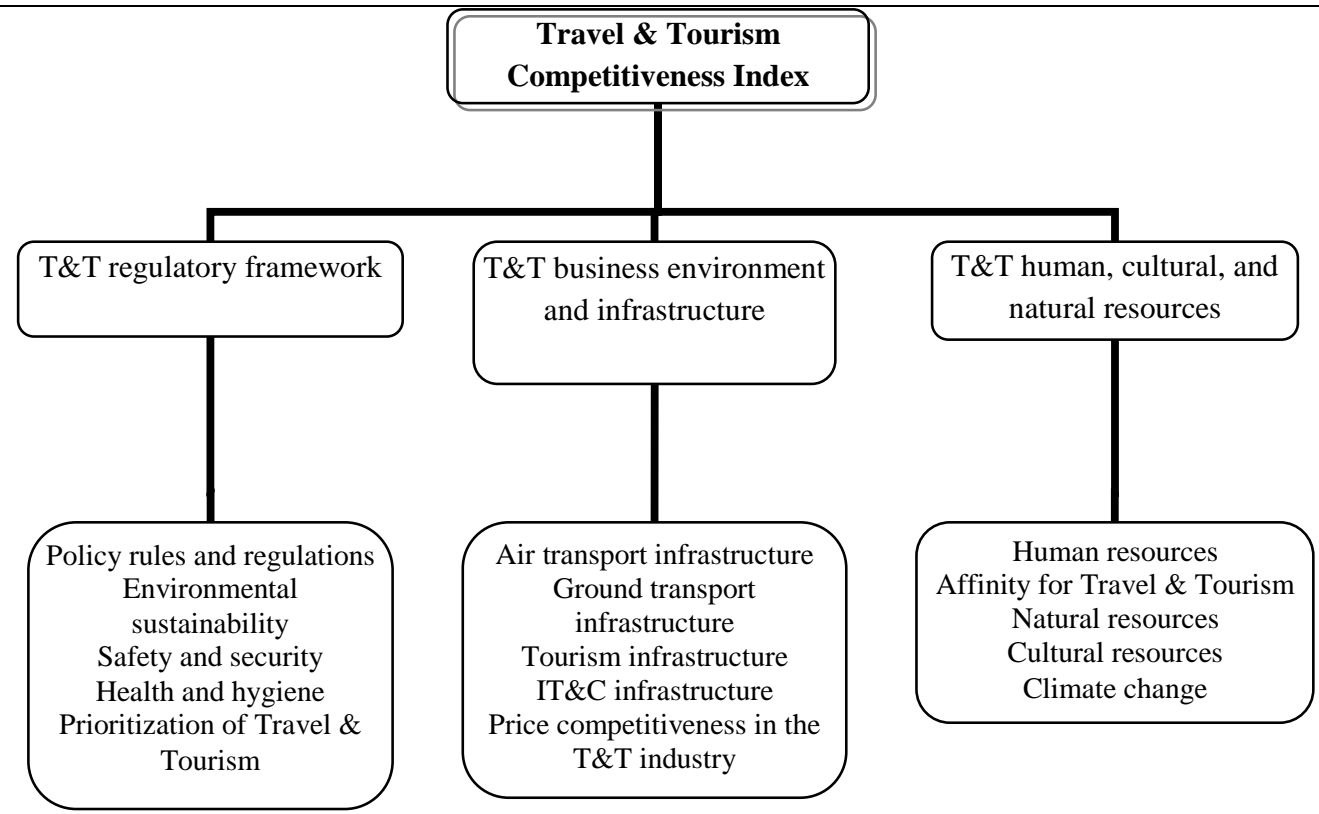

IT\&C = Information, Technology, and Communication

Source: Croitoru (2011) 
From 2015, the structure of the general framework of the Travel and Tourism Competitiveness Index changed. From a form with three sub-indices, it was revised to contain four sub-indices as shown in Figure 2. It was important that most parts of the pillars of competitiveness remained unchanged.

Figure 2: Components of the Travel \& Tourism Competitiveness Index (TTCI) in the year 2015

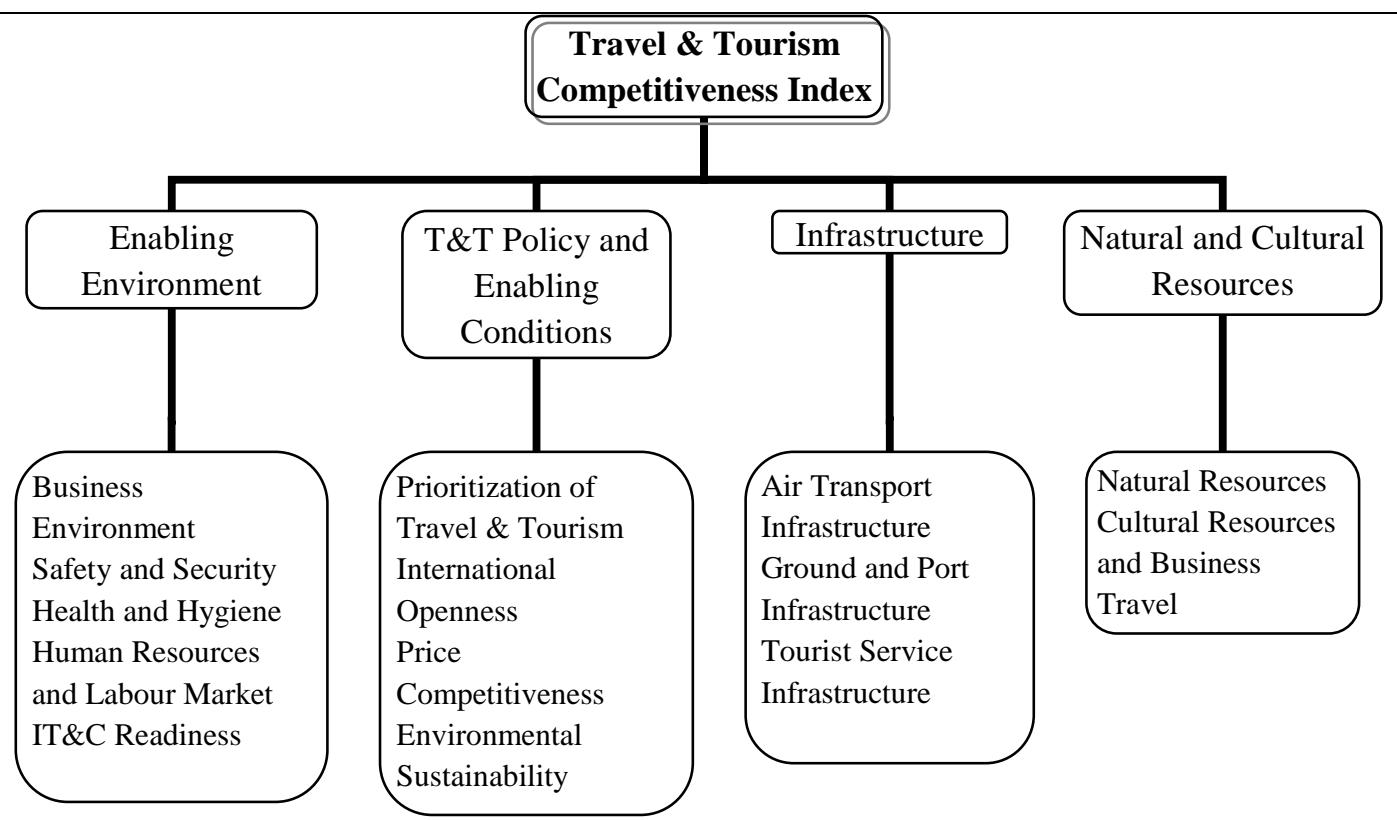

IT\&C = Information, Technology, and Communication

Source: The Travel and Tourism Competitiveness Report (2015)

The necessary data to compile scenarios for each pillar in the analysis of tourism competitiveness were obtained for both models from direct statistical research of the World Economic Forum report, and secondary sources of international organizations, institutions, and surveys carried out by experts in the field of tourism.

The Travel and Tourism Competitiveness Index was not only used for scoring, but also to evaluate the tourism activity of the different countries, to enable a comparative analysis of the performance scores obtained. The first part of our comparative analysis was based on the data from the World Economic Forum from reports on tourism competitiveness in 2011-2015.

The second part of the comparative analysis was focused on both the quantitative but more so the qualitative aspects of our study into the tourism competitiveness between the seaside districts of Romania and Bulgaria. Within our quantitative analysis, the following work hypotheses applied:

- Hypothesis 1: The total number of arrivals registered for the Romanian seaside is below the number registered for the Bulgarian seaside.

- Hypothesis 2: The total number of arrivals of foreign tourists for the Romanian seaside is below the number registered for the Bulgarian seaside.

- Hypothesis 3: The general level of classification (number of stars) of hotels situated in the Romanian seaside area is below the level of classification of hotels for the Bulgarian seaside.

The data used (relative to the period 2008-2014) was taken from the National Authority for Tourism, Romania (2015), the National Institute of Statistics, Romania (2015), and the National Institute of Statistics, Bulgaria (2015), and were processed using Microsoft Excel (2007).

Romania versus Bulgaria from the point of view of the Travel \& Tourism Competitiveness Index

From the data provided by the last World Economic Forum Report (The Travel and Tourism Competitiveness Report, 2015), Romania ranked 66 out of 141 countries, as opposed to Bulgaria, a 
direct competitor, which ranked 49. The development of these countries in the Travel and Tourism Competitiveness Index and their position in the world as a whole, are presented in Table 1.

Table 1: The comparative analysis Romania-Bulgaria, regarding the development of the Travel \& Tourism Competitiveness (TTCI) Index during 2011-2015

\begin{tabular}{||l|c|c|c|c|c||}
\hline \multirow{2}{*}{} & \multicolumn{2}{|c|}{ TTCI Index 2015 } & \multicolumn{2}{c||}{ TTCI Index 2013 } & TTCI Index 2011 \\
\cline { 2 - 7 } & $\begin{array}{c}\text { Position out } \\
\text { of 141 } \\
\text { countries }\end{array}$ & $\begin{array}{c}\text { Index } \\
\text { value }\end{array}$ & $\begin{array}{l}\text { Position out } \\
\text { of } 140 \\
\text { countries }\end{array}$ & $\begin{array}{c}\text { Index } \\
\text { value }\end{array}$ & $\begin{array}{c}\text { Position out of 139 } \\
\text { countries }\end{array}$ \\
\hline Romania & 66 & 3.78 & 68 & 4.04 & 63 \\
\hline Bulgaria & 49 & 4.05 & 50 & 4.38 & 48 \\
\hline
\end{tabular}

Source: The Travel and Tourism Competitiveness Report (2015)

Table 2 shows the scores for each component pillar of the TTCI. In the context of tourism at the European level, Romania ranked 32 from 42 positions, with Bulgaria, a direct competitor, ranking 28. It should be noted that, globally, the European countries rank well in the TTCI, especially despite most of these countries having been seriously affected by the global financial crisis of 2008, which lead to important reductions in the volume of investments and particularly income from tourism activity.

In comparison with the neighboring country, Romania was ranked unfavorably, although the conditions to achieve tourism activity were mainly similar. From the point of view of the pillars on which the tourism competitiveness relies, Romania exceeds Bulgaria in safety and security (based on delinquency rate and number of terrorist attacks); the prioritization of tourism activity; government understanding of tourism importance and its allocation of funds; national and international tourism marketing campaigns; and the country's branding (Table 2). In addition, the international openness, which is the availability and the openness of the country to sign different bilateral agreements, the number of regional trade agreements, and cultural resources play a role (Table 2). The differences registered in the case of these elements are, nonetheless, minor.

Table 2: The comparative analysis Romania-Bulgaria from the point of view of the scores obtained for the 14 TTCI pillars

\begin{tabular}{|c|c|c|c|c|c|c|c|}
\hline \multirow[b]{2}{*}{$\begin{array}{l}\text { Country/Economy } \\
\text { NORTHERN AND EASTERN EUROPE }\end{array}$} & \multicolumn{2}{|c|}{ TTCI INDEX } & \multicolumn{5}{|c|}{ Enabling Environment Pillars, values } \\
\hline & Regional rank & Global rank & $\begin{array}{c}\text { Business } \\
\text { Environment }\end{array}$ & $\begin{array}{l}\text { Safety and } \\
\text { Security }\end{array}$ & $\begin{array}{l}\text { Health and } \\
\text { Hygiene }\end{array}$ & $\begin{array}{c}\text { Human } \\
\text { Resources and } \\
\text { Labour Market }\end{array}$ & ICT Readiness \\
\hline Bulgaria & 28 & 49 & 4.22 & 5.24 & 6.70 & 4.72 & 4.76 \\
\hline Romania & 32 & 66 & 4.11 & 5.42 & 5.94 & 4.56 & 4.36 \\
\hline Europe and Caucasus average & & & 4.61 & 5.76 & 6.20 & 4.90 & 5.04 \\
\hline Best performer (global) & & & 6.13 & 6.70 & 6.97 & 5.64 & 6.37 \\
\hline
\end{tabular}

\begin{tabular}{|c|c|c|c|c|c|c|c|c|c|}
\hline \multirow[b]{2}{*}{ Country/Economy } & \multicolumn{4}{|c|}{$\begin{array}{l}\text { T\&T Policy and Enabling } \\
\text { Conditions Pillars, values }\end{array}$} & \multicolumn{3}{|c|}{$\begin{array}{l}\text { Infrastructure } \\
\text { Pillars, values }\end{array}$} & \multicolumn{2}{|c|}{$\begin{array}{c}\text { Natural and Cultural } \\
\text { Resources Pillars, values }\end{array}$} \\
\hline & $\begin{array}{l}\text { Prioiritization } \\
\text { of T\&T }\end{array}$ & $\begin{array}{l}\text { International } \\
\text { Openness }\end{array}$ & $\begin{array}{c}\text { Price } \\
\text { Competitive- } \\
\text { ness }\end{array}$ & $\begin{array}{l}\text { Environmental } \\
\text { Sustainability }\end{array}$ & $\begin{array}{l}\text { Air Transport } \\
\text { Infrastructure }\end{array}$ & $\begin{array}{c}\text { Ground } \\
\text { and Port } \\
\text { Infrastructure }\end{array}$ & $\begin{array}{l}\text { Tourist Service } \\
\text { Infrastructure }\end{array}$ & $\begin{array}{c}\begin{array}{c}\text { Natural } \\
\text { Resources }\end{array} \\
\text { ent }\end{array}$ & $\begin{array}{c}\text { Cultural } \\
\text { Resources \& } \\
\text { Business Trave }\end{array}$ \\
\hline Bulgaria & 4.18 & 3.87 & 5.08 & 4.62 & 2.46 & 3.26 & 6.06 & 3.44 & 1.96 \\
\hline Romania & 4.34 & 3.91 & 4.89 & 4.35 & 2.34 & 3.10 & 5.01 & 2.70 & 2.07 \\
\hline Europe and Caucasus average & 4.76 & 3.61 & 4.19 & 4.47 & 3.43 & 4.33 & 5.14 & 3.09 & 2.57 \\
\hline Best performer (global) & 6.03 & 5.25 & 6.62 & 5.63 & 6.75 & 6.45 & 6.83 & 6.01 & 6.69 \\
\hline
\end{tabular}

Note: Dark green = very strong performance, dark red = weak performance, and yellow = average performance, compared to the best/worst performers on each pillar, globally.

Source: The Travel and Tourism Competitiveness Report (2015) 
Noticeable, both Romania, and Bulgaria, suffer in several avenues. An analysis of each of the 14 pillars of competitiveness by awarding a score of 1 to 7, with 1 representing the minimum and 7 the maximum score, showed the weakest fields in performance and competitiveness in tourism are those relating to general transport infrastructure (air, ground, and water transport) and the cultural resources of the two countries. In terms of general transport infrastructure, the results were predictable, especially with the lack of highways and modern airports and the extremely low average speed of the trains. Regarding the cultural resources, which weigh towards meeting conditions of efficiency and competitiveness, there are a number of monuments included in the UNESCO heritage and their density, particularly the number of stadiums of sufficient capacity to host special events at the European level or world level (e.g. concerts, and sporting events). An important indicator for the analysis of cultural resources is the number of online searches on the cultural resources of a country.

It is interesting from the point of view of natural resources, that Bulgaria clearly surpasses Romania, in respect to WEF data, ranking 48 globally, as opposed to Romania, which only ranked 79 . The elements evaluated were the number of areas included in the UNESCO World Heritage, the quality of the natural environment, the richness of the fauna, and the rate or percentage of protected natural areas (national parks and wildlife preserves).

Romania, as a tourism destination, has an advantage, at least in comparison with other European countries, in the various tourism potential that can sustain major tourism, e.g. mountain, cultural, balneary, seaside, and adventure. However, this tourism potential is inadequate for transforming Romania into a strong tourism destination that would genuinely attract tourists from everywhere. The best performing pillar in the case of both Romania Bulgaria, was health and hygiene (6.70 points from 7.00 possible in the case of Bulgaria, and 5.94 points in the case of Romania). This element is quantified based on access to superior quality drinking water and the level of public health services (i.e. the number of doctors and the number of hospital beds).

In comparison with the European average and the Caucasian zone average, the scores for the 14 pillars of tourism competitiveness was higher for Romania for the international openness and price competitiveness. This indicated Romania was still an accessible destination for foreign tourists, especially with the level of airport taxes, and particularly with the cost of accommodation and public food services. On the subject of price, Romania was the third most attractive European destination, after Bulgaria (absolute leader) and Poland. However, at the global level, Romania ranked 54 out of 141 countries, as opposed to Bulgaria, which ranked 35. The factor that made Bulgaria the most economical European tourism destination was the quality to price ratio, which was superior to that of Romania. Also, Bulgaria had gained over time the status of an All Inclusive destination (especially, with the seaside area), and had become unbeatable in this area, because many Romanians chose to stay at the Bulgarian seaside for the summer holidays.

In order to reduce this difference, Romanian hotel owners had begun to introduce All Inclusive packages. The number of hotels that adopted this system remained less than that of Bulgaria, and this was the main reason for the reticence of the Romanian managers about the inexistence of a massive demand on the tourism system. They understand the language and the location, and thus Romanian tourists preferred to have meals on their own at varying places that were not "linked" to the services of one hotel or restaurant. The demand of the Romanian tourists for the All Inclusive system was quite important in the case of external destinations, where they did not know the language or the local area. In Bulgaria, the All Inclusive system functioned very well due to the increasing number of foreign tourists (German, Romanian, English, or Russian) who did not wish to be concerned about organizing meals and additional costs.

Apart from price competitiveness, Bulgaria gained a superior position in comparison with the European average, including in subjects of health and hygiene, natural resources, environmental sustainability, and international openness. An important positive difference can be noticed with tourism infrastructure, with Bulgaria benefiting with the beginning of a vast process of privatization, from critical investments in the hotel industry, large hotel chains like Sol Melia, Best Western, Primasol, Grifid, or Riu, entering the Bulgarian market. 


\section{Particularities and competitiveness elements of the tourism activity on the Romanian seaside and the Bulgarian seaside}

The tourism activity in the two countries was mainly sustained by the same type of components. While Romanian tourism was considered and managed from the perspective of the three basic natural assets: the Carpathians, the Danube, and the Black Sea, which add to the cultural component in religious, ethnographical, and museum aspects, and the variety of the balneary potential, Bulgaria capitalized on mountain areas represented by the Rila, Pirin (with 260 glacial lakes), Rodopi, Srenda Gora, and the Balkan Mountains (Stara Planina), and especially its $380 \mathrm{~km}$ shoreline of the Black Sea. While in Romania a niche or a predominant form of tourism had not been yet crystallized, Bulgaria was seen as a tourism destination through its seaside area, which every year attracted about $70 \%$ of all tourists visiting that country. In the case of seaside tourism, the differences between the two countries began to appear and gradually deepen after the Revolution, when management, promotion, and development of the tourism heritage regarding the Black Sea coast and, especially the tourism activity itself, developed separately.

The coastline of Romania is $245 \mathrm{~km}$ long, which is shorter than Bulgaria's $378 \mathrm{~km}$ length of coastline. However, this aspect has little importance in explaining the differences between the tourism performance of the two neighboring countries. The differences registered in recent years between these destinations originated with the market economy after the fall of the communist regime, when the hotel industry was privatized. Bulgaria gained advantage by beginning the privatization of hotels before Romania. Also, the Romanians chose to award the commercial hotel leases to ex-employees, and this, in most cases, was performed without the hotel management's knowledge and without a longterm vision of the development of the seaside tourism sector. In contrast, the Bulgarians preferred to privatize the hotel industry in a "healthier" manner, from a strategic standpoint of signing contracts with large overseas hotel chains and several important worldwide tour-operator agencies, e.g. Touristik Union International (TUI), Thomas Cook, and Der Tour. These agencies, mostly German, had the expertise to direct tens of thousands of German tourists towards Bulgarian resorts. Moreover, the difference between the two countries deepened, beginning in 2007, when Bulgaria received a superior allocation of the European funds for the tourism sector.

Figure 3 shows the Bulgarian seaside had between 1.5 and 1.6 million tourists arrive annually to obtain accommodation in different tourism establishments with about $80 \%$ being foreign tourists. In comparison, 0.7 million tourists arrived in Romania annually to obtain accommodation in different establishments, with about 5\% representing tourists arriving from abroad. Thus Hypotheses 1 and 2 are accepted.

The Bulgarian seaside was promoted as having a large range of accommodation services, from hotels and motels to guesthouses and bungalows. There was also a diversified range regarding the accommodation available on the Romanian seaside. Nevertheless, the most attractive tourism accommodation were hotels in areas of the Black Sea coast. Hence, the analysis in the following sections will focus on this form of accommodation. The Romanian seaside hotels, classified by the National Authority of Tourism as 2- and 3-star categories, included many superficially restored and with services of questionable quality. In contrast, more than half the Bulgaria seaside hotels were classified as 3- and 4-star accommodation, with high quality services (Figure 4). This tendency is expected to increase, especially with the number of new hotels in Bulgaria surpassing that registered for Romania. Thus, we submit that Hypothesis no. 3 is accepted.

The largest Romanian seaside resorts (in terms of hotel numbers) are Mamaia and Eforie Nord, while those for Bulgaria are the Sunny Beach and Golden Sands resorts. These four resorts are the most important with their associated hotels exhibiting 4- and 5-star levels of classification.

Figure 4 shows that the Bulgarian seaside had more 4- and 5-star hotels than Romania. While the coastal area of Romania had very few 5-star hotels, with these only in Mamaia, Mamaia Nord (Năvodari), Venus, and Saturn, the seaside area of Bulgaria had such hotels in most resorts. The same situation applied with 4-star hotels, though the difference was more evident. Despite foreign tourists generally preferring hotels with high standards (4- and 5-star), it is possible that the Bulgarian seaside merely attracts more foreign tourists during summer compared with the situation at the Romanian coast of the Black Sea. 
Figure 3: Number of arrivals in the tourist accommodation establishments, within the period 20082014

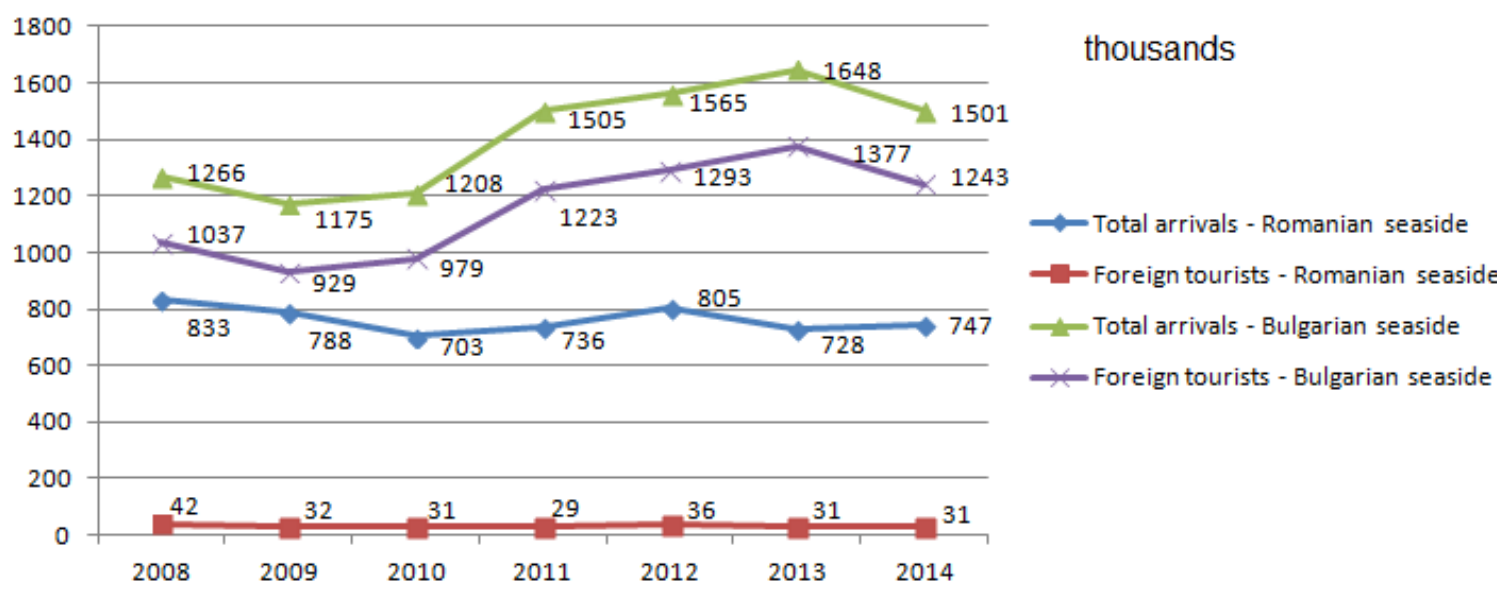

Source: National Institute of Statistics, Romania (2015), National Institute of Statistics, Bulgaria (2015)

Figure 4: The hotels along the Romanian seaside and along the Bulgarian seaside, according to hotel star rating

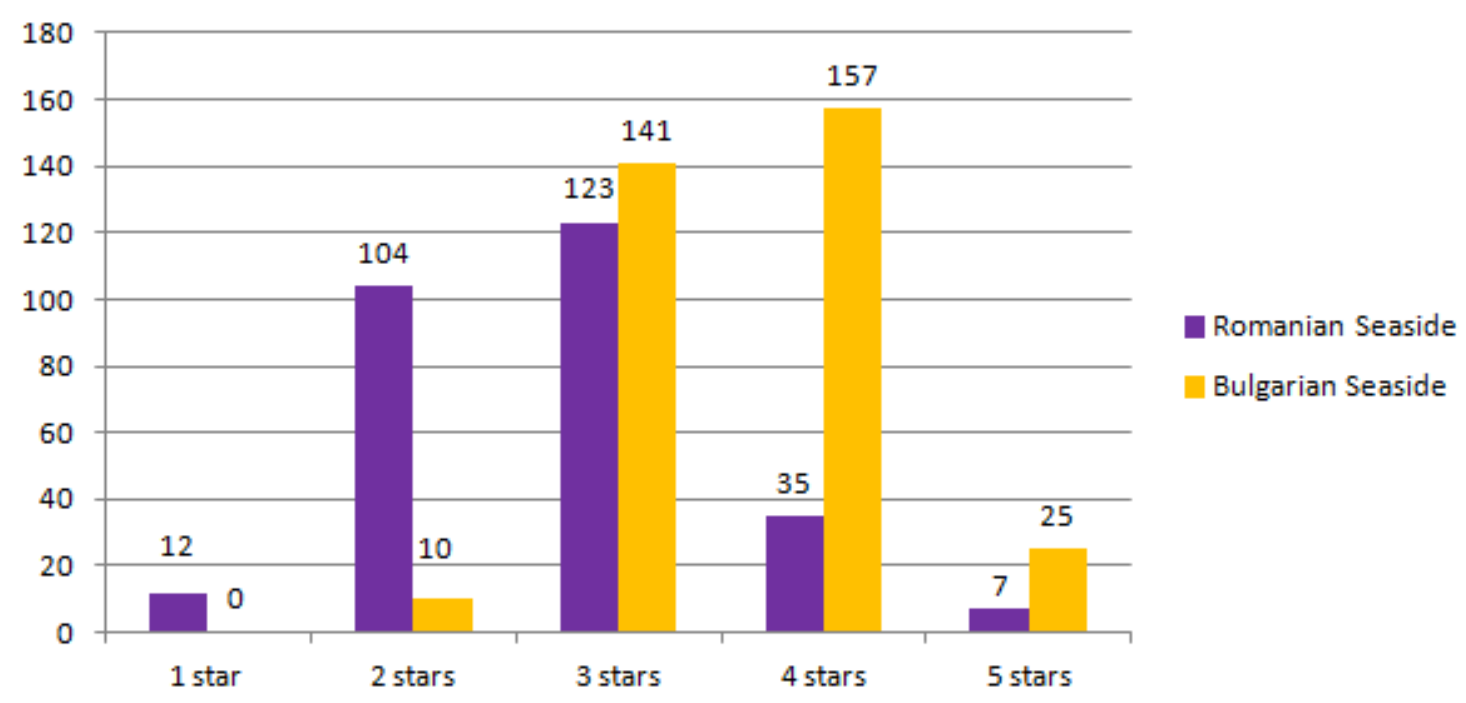

Source: National Authority for Tourism, Romania (2015), National Institute of Statistics, Bulgaria (2015)

From the perspective of the seaside hotel industry, both countries had high potential, but the difference between Romania and Bulgaria is that in the South of the Danube (Bulgaria) people have a more profound appetite and wider openness for foreign investors and thus are inclined to modernize and build new hotels. In recent years, especially after the countries joined the European Union in 2007, the hotel industry of Romania followed a process of extension and modernization with the help of European funds and relevant financing lines that sustained the tourism activity. Nevertheless, Bulgaria benefited from this same process of extension and modernization. Moreover, most investments 
materialized for rural tourism, where new accommodation establishments were extended and built under the form of tourism and agritourism guesthouses. Subsequently, in the case of Romanian, at least, the seaside area was less apparent on the chart of investments in hotel infrastructure investment through European funds.

The high level of standards imposed by the hotel industry in the seaside area of Bulgaria reflected the strong competition among tourism accommodation establishments, especially regarding the service performance. As Lukanova (2010) well noticed, these standards represented, at the time, barriers against new hotel owners entering the market, especially when the standard imposed and promoted by them was not raised at the general level of the market.

The opportunities offered by tourism potential of a country may be capitalized and turned into profit on a technical-material basis that directly reflects the superior quality of services offered. Without general infrastructure, no tourism resource (no matter how important) is viable. Thus, we unequivocally state that the insufficient development of infrastructure in Romania represented the prime factor in Romania's incapacity to develop tourism and its serious deficiencies in returning profits in the national supply. Apart from hotel infrastructure, general transport infrastructure, especially air transport, is an important factor at the base of the competitiveness of the Bulgarian seaside. The seaside area of Bulgaria benefits from two international airports, one in Varna and the other in Burgas. These connect the Bulgarian Riviera with the rest of the world. By comparison, Romania has only one international airport (in Constanța), with one charter flight each week operating between Romania and Israel. Turkish Airlines also operates from this airport with its line offering weekly flights between Istanbul and Constanța, with a stopover in Varna.

A positive aspect in the absence of charter flights, is that Blue Air and Wizz Air, both low-cost companies, ensured a flux of tourists between Milan and Constanta, in the case of Blue Air, and London and Constanța, in the case of Wizz Air. The Hungarian Wizz Air is the largest air company on the local market, according to the number of transported passengers, and entered the arena in early June 2015 with two flights each week from "Mihail Kogălniceanu" airport of Constanța to London (Tufan, 2015). In contrast, there was no direct connection between Constanta and the German market. The lack of partnerships with large German tour-operators that included the Romanian seaside as a holiday destination in their catalogues affected the situation.

In the case of the Bulgarian seaside, apart from the already classic partnerships with the large German tour-operators that annually send hundreds of thousands of tourists to the sunny beaches of the Bulgarian Riviera, recent partnerships had formed with a series of Russian tour-operators. Among these were the well-known Coral Travel and Pegas Touristik agencies. At the start of the last year, the Bulgarian tour-operators expected an increase of $40-50 \%$ in the number of Russian tourists, in comparison with the previous year. However, Russia's economic status, determined by the international geopolitical situation, and, implicitly, the devaluation of the rouble, moderated this outcome. Nevertheless, in 2013, the Bulgarian seaside had about 225,000 Russian tourists spending their holidays in their area and this was over five times the total number of foreign tourists (irrespective of the country) holidaying at the Romanian seaside (Capital.ro, 2014).

The high number of beaches classified with the "blue flag", which recognizes beaches on the international plan, also determined the success of the Bulgarian seaside. Offered by a non-profit foundation for education of environmental issues, the "blue flag" distinguishes quality beaches with respect to impeccable cleanliness and immaculate service. At the global level3,468 beaches respect the international criteria of quality (Blue Flag, 2015). These were mostly in Spain (578 beaches), Greece (395), and Turkey (436). Bulgaria had nine such beaches distinguished by blue flag with some resorts having two or three, as was the case with the Sveti Vlas resort, which had three "blue flag" beaches, and Sunny Beach, which had two. Unlike Bulgaria, Romania had only one beach distinguished by the "blue flag", which was Vega Vintage beach, belonging to Vega Hotel in Mamaia. Romania originally had eight internationally recognized beaches, but because of seaweed, garbage, and chaotic buildings, the number in 2006 was reduced to one, situated in the northern part of the Mamaia resort.

In order to obtain such a distinction of international recognition, a beach must be manually and mechanically cleaned every evening. It is recommended that deep cleaning of the sand is performed to eliminate cigarette butts, shells, and other wastes. However, these are not the only criteria, with at least 
29 such elements for beach administrators to consider to ensure inclusion of ecological education, availability of dustbins and sanitary facilities, and removal of undesirable vegetation or seaweed.

A possible explanation for the lack of interest by local authorities and private organizations in ensuring conditions meet the blue flag criteria for their beaches could relate to the predominance of Romanian tourists at the resorts of the Romanian seaside. Romanians are not usually interested in whether or not a beach has the "blue flag" distinction. Many are unaware of its relevance or the values it denotes. This situation will need changing to develop and attract foreign tourists to the seaside area of Romania, especially as such a destination should have at least one internationally certified beach. Moreover, we propose that Romanian tourists who have travelled abroad, at least once, to a popular international seaside destination (e.g., Greece, Turkey) will have an increased preference for certified beaches for when they choose to spend their holidays within the country.

Romanian beaches, apart from not meeting conditions of certification of the "blue flag", suffer from continuous degradation. The erosion of beaches, which worsens each year is well known. The Romanian authorities have implemented actions to stop this phenomenon with varying intensity, including a project financed by European funding, where authorities have attempted to locate dams offshore and used tetrapods filled with sand in these locations.

\section{Result and Discussion}

The results of this study show that, although both countries had mainly similar opportunities for development of tourism, there remains many elements indicating the superior competitiveness of tourism activity in the Bulgarian seaside destination compared with that of the Romanian destination.

These include the fact that the weather is milder in Bulgaria. Though not major, the difference enables Bulgarian visitors to benefit from a longer summer season (at least, in the case of the resorts situated along the south coast of the Black Sea) than that experienced in Romania. The natural conditions are not everything. Another element indicating the superior competitiveness of Bulgarian seaside is the way of understanding of the hotel privatization. The beginning of privatization in Bulgaria was in 1993, with most hotels acquired by foreign investors, international hotel chains, or large tour-operator agencies. The privatization of hotels in Romania began much later, with the tourism accommodation becoming the property of ex-employees or investors without genuine capacity for management in tourism. Here is a possible cause of the fact that many hoteliers situated along the Romanian seaside have ignored accommodation conditions of comfort and hygiene. Very few Romanian hotel owners have invested in tourism infrastructure, and direct foreign investments have been absent in recent years.

Romanian leaders who organized the privatization of the hotels did not understand the importance of involving large hotel chains or travel agencies in this process, and their direct investment and their expertise. A noteworthy mention is that, apart from having comparative advantages, Bulgaria became superior in tourism competitiveness because of the deficiencies that still characterize the Romanian seaside area. An urgent problem to be solved is the negative image of Romania abroad that decreases the attractiveness of the Romanian seaside. The promotion of the destination is insufficient to counteract such negative image. Therefore, we believe that in addition to legislative measures, economic and fiscal measures and investments in general and tourism infrastructure (especially with transport infrastructure that was insufficiently optimized for seasonal heavy traffic), Romania must show a pronounced concern for promoting the local destinations abroad.

\section{Conclusion}

Tourism is undoubtedly a sector that can sustain the economy of countries such as those in the eastern part of Europe. The tourism industry stands out as one of the main generators of jobs globally, but also as a strong global manufacturer in terms of gross domestic product. Therefore, this sector should be treated and developed with great care and skill in each country.

The analysis conducted reveals that although Romania and Bulgaria are two countries with many similarities, tourism activity shows different characteristics. The level of tourist activity in Bulgaria is superior to that of Romania. In this sense, obvious gaps are recorded. Bulgaria has proved to be an internationally competitive tourist destination. This should be seen by Romania as an example to follow in order to improve the local tourism activity level. Basically, Romania should aim to recover 
as much as possible these gaps recorded at investments, infrastructure, politics, strategies, promotion, and results.

We appreciate that the entire tourism activity from Romanian Seaside suffers and therefore it is imperative for urgent action to allow creating and implementing marketing and organizational strategies in order to improve all aspects related to developing local tourism. This implies a thorough research of tourist activity in the neighboring country, in order to be able to import some good practices, but also to learn from the possible mistakes made by them.

We also consider that Romania should relate to other countries such as Turkey, Greece, Spain or Croatia, that demonstrated in recent decades their relevance on the most important markets. These countries may also constitute the best examples to follow for Romania.

This research does not necessarily claim to present in an exhaustive manner all the issues of Romanian and Bulgarian Seaside tourism, but wants to represent a simple argument to convince the public and private actors in the hospitality industry, to begin a systematic study of tourism from other countries in a continuous and professional approach. Especially since as we have seen, Romanian Seaside has the necessary resources in order to recover the performance gaps and to eventually become a tourist destination internationally acclaimed.

\section{References}

Bonn, M. A., Joseph, S. M., \& Dai, M. (2005). International versus domestic visitors: An examination of destination image perceptions. Journal of Travel Research, 43(3), 294-301. Retrieved from http://jtr.sagepub.com/content/43/3/294.short

Boșcoianu, M., Costea, M., \& Codreanu, A. (2015). Sovereign investment funds and the globalization of tourism. Discussions on Romania`s case. Journal of Defense Resources Management, 6(1), 85.

Blue Flag (2015). Retrieved November 5, 2015, from http://www.blueflag.org/

Capital.ro (2014, July 11). Most visitors from Bulgarian seaside ar Germans and Romanians . Retrieved November 5, 2015 , from http://www.capital.ro/cei-mai-multi-vizitatori-de-pe-litoralul-bulgaresc-sunt-nemti-si-romani.html

Chen, C. F., \& Tsai, D. (2007). How destination image and evaluative factors affect behavioral intentions? Tourism management, 28(4), 1115-1122. Retrieved from http://www.sciencedirect.com/science/article/pii/S0261517706001397

Chi, C. G. Q., \& Qu, H. (2008). Examining the structural relationships of destination image, tourist satisfaction and destination loyalty: An integrated approach. Tourism management, 29(4), 624-636. Retrieved from http://www.sciencedirect.com/science/article/pii/S0261517707001525

Chon, K. S., \& Mayer, K. J. (1995). Destination competitiveness models in tourism and their application to Las Vegas. Journal of Tourism Systems and Quality Management, 1(2), 3.

Croitoru, M. (2011). Tourism Competitiveness Index - An Empirical Analysis Romania vs. Bulgaria. Theoretical and Applied Economics, 9(562), 155-172.

Crouch, G. I. (2010). Destination competitiveness: An analysis of determinant attributes. Journal of Travel Research. Retrieved from http://jtr.sagepub.com/content/early/2010/03/19/0047287510362776.abstract

Dwyer, L., Forsyth, P., \& Rao, P. (2000). The price competitiveness of travel and tourism: a comparison of 19 destinations. Tourism Management, 21(1), 9-22. Retrieved from http://www.sciencedirect.com/science/article/pii/S0261517799000813

Enright, M. J., \& Newton, J. (2005). Determinants of tourism destination competitiveness in Asia Pacific: Comprehensiveness and universality. Journal of travel research, 43(4), 339-350. Retrieved from http://jtr.sagepub.com/content/43/4/339.short

Gallarza, M. G., Saura, I. G., \& García, H. C. (2002). Destination image: Towards a conceptual framework. Annals of tourism research, 29(1), 56-78. Retrieved from http://www.sciencedirect.com/science/article/pii/S0160738301000317

Gomezelj, D. O., \& Mihalič, T. (2008). Destination competitiveness-Applying different models, the case of

Slovenia. Tourism management, 29(2), 294-307. Retrieved from

http://www.sciencedirect.com/science/article/pii/S0261517707000714

Hassan, S. S. (2000). Determinants of market competitiveness in an environmentally sustainable tourism industry. Journal of Travel Research, 38: 239:245.

Hong, W. C. (2008). Competitiveness in the tourism sector. A comprehensive approach from economic and management points. Physica-Verlag (a Springer company). Retrieved from

https://books.google.ro/books?id=9BVFG8FaMncC\&printsec=frontcover\&hl=ro\#v=onepage\&q\&f=false

Hsu, C. H. C, Wolfe, K., \& Kang, S. K. (2004). Image assessment for a destination with limited comparative advantages. Tourism Management, 25: 121-126.

Hu, Y. Z, \& Ritchie, J. R. B. (1993). Measuring destination attractiveness: A contextual approach. Journal of Travel Research, 32: 25-34.

Ioncică, M., Petrescu, E. C., \& Ioncică, D. (2008). Abordări macro și microeconomice ale competitivității în sectorul serviciilor. Revista de Marketing Online, 2 (1), 76. 
Ivanov, S. H., \& Webster, C. (2013). Globalisation as a driver of destination competitiveness. Annals of Tourism Research, 43, 628-633. Retrieved from

https://www.researchgate.net/profile/Stanislav_Ivanov/publication/259098521_GLOBALISATION_AS_A_DRIVER_OF_D ESTINATION_COMPETITIVENESS/links/5430e3f60cf29bbc12772604.pdf

Lukanova, G. (2010). Evaluation of hotel service performance process in Bulgaria. UTMS Journal of Economics, Retrieved from

http://www.doaj.org/doaj?func=search\&page=2\&template=\&query=bulgaria\%20tourism\&currentYear=2013\&uiLanguage=e $\mathrm{n}$

Mazanec, J. A., Wöber, K., \& Zins, A. H. (2007). Tourism destination competitiveness: from definition to explanation? Journal of Travel Research,46(1), 86-95. Retrieved from https://www.researchgate.net/profile/Josef_Mazanec/publication/249701318_Tourism_Destination_Competitiveness_From_ Definition_to_Explanation/links/02e7e53c21c6f75f91000000.pdf

Murphy, P., Pritchard, M. P., \& Smith, B. (2000). The destination product and its impact on traveller perceptions. Tourism management, 21(1), 43-52. Retrieved from http://www.sciencedirect.com/science/article/pii/S0261517799000801

National Authority for Tourism, Romania (2015).Turism.gov.ro. Retrieved 6 november, 2015, from http://turism.gov.ro/wpcontent/uploads/2013/05/StructuriCazareClasificate250420161-1.xls

National Institute of Statistics, Bulgaria (2015). Infostat.nsi.bg. Retrieved 5 November, 2015, from https://infostat.nsi.bg/infostat/pages/reports/query.jsf?x_2=203

National Institute of Statistics, Romania (2015). Insse.ro. Retrieved 5 November, 2015, from http://statistici.insse.ro/shop/index.jsp?page=tempo3\&lang=ro\&ind=TUR104BNavickas, V., \& Malakauskaite, A. (2015).

The possibilities for the identification and evaluation of tourism sector competitiveness factors. Engineering Economics, 61(1). Retrieved from http://eis.ktu.lt/index.php/EE/article/viewFile/11581/6264

Poon, A. (1993). Tourism, technology and competitive strategies. Cab International Publication.

Prayag, G., \& Ryan, C. (2012). Antecedents of tourists' loyalty to Mauritius The role and influence of destination image, place attachment, personal involvement, and satisfaction. Journal of Travel Research, 51(3), 342-356. Retrieved from https://www.researchgate.net/profile/Girish_Prayag/publication/258161250_Antecedents_of_Tourists_Loyalty_to_Mauritius _The_Role_and_Influence_of_Destination_Image_Place_Attachment_Personal_Involvement_and_Satisfaction/links/55074fc 00cf26ff55f7cf889.pdf

Qu, H., Kim, L. H., \& Im, H. H. (2011). A model of destination branding: Integrating the concepts of the branding and destination image. Tourism Management, 32(3), 465-476. Retrieved from

http://media.bizwebmedia.net/sites/146527/upload/documents/2-destination-_image_2.pdf

Ritchie, J. B., \& Crouch, G. I. (1993). Competitiveness in international tourism: A framework for understanding and analysis. World Tourism Education and Research Centre, University of Calgary.

The Travel and Tourism Competitiveness Report (2015). Retrieved from http://www3.weforum.org/docs/TT15/WEF_Global_Travel\&Tourism_Report_2015.pdf

Tufan, M. (2015, June 25). Wizz Air a mai bifat un aeroport în România: din iunie a intrat cu zboruri pe ruta Constanţa Londra, Ziarul Financiar [Wizz Air has checked an airport in Romania : in June came flying Constanta - London route, Ziarul Financiar]. Retrieved from http://www.zf.ro/companii/wizz-air-a-mai-bifat-un-aeroport-in-romania-din-iunie-a-intratcu-zboruri-pe-ruta-constanta-londra-14502802

Zhang, H., Gu, C. L., Gu, L. W., \& Zhang, Y. (2011). The evaluation of tourism destination competitiveness by TOPSIS \& information entropy-A case in the Yangtze River Delta of China. Tourism Management, 32(2), 443-451. Retrieved from https://www.ischool.utexas.edu/ Yanz/YanZhang_CV2011.pdf 